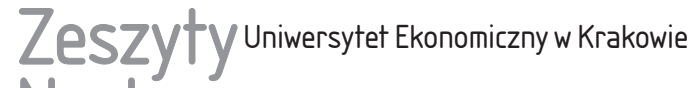 Naukowe
}

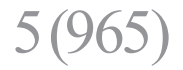

ISSN 1898-6447

Zesz. Nauk. UEK, 2017; 5 (965): 51-67 DOI: 10.15678/ZNUEK.2017.0965.0504

Andrzej Czyżewski

Aleksander Grzelak

\section{Wykorzystanie modelu przepływów międzygałęziowych do ocen makroekonomicznych gospodarki}

\section{Streszczenie}

Celem artykułu jest przedstawienie możliwości wykorzystania modelu przepływów międzygałęziowych do ocen makroekonomicznych gospodarki, z uwzględnieniem dotychczasowych doświadczeń i propozycji na przyszłość. W trakcie badań stwierdzono, że model przepływów międzygałęziowych stanowi użyteczny instrument oceny i interpretacji zjawisk gospodarczych. Przede wszystkim chodzi tu o ocenę związków, a także zdiagnozowanie źródeł zróżnicowanego rozwoju pomiędzy działami w obrębie gospodarki danego kraju. Istnieje potrzeba rozbudowy interpretacji modelu przepływów międzygałęziowych o czwartą część tablicy przepływów, co oznacza konieczność publikacji danych dotyczących podziału wytworzonych dochodów. W dalszej kolejności interesująca byłaby próba wykorzystania tego modelu do prezentacji skali nierównowagi podażowej w gospodarce oraz uwzględnienie kontekstu środowiskowego analiz makroekonomicznych.

Andrzej Czyżewski, Uniwersytet Ekonomiczny w Poznaniu, Wydział Ekonomii, Katedra Makroekonomii i Gospodarki Żywnościowej, al. Niepodległości 10, 61-875 Poznań, e-mail: Andrzej.Czyzewski@ue.poznan.pl

Aleksander Grzelak, Uniwersytet Ekonomiczny w Poznaniu, Wydział Ekonomii, Katedra Makroekonomii i Gospodarki Żywnościowej, al. Niepodległości 10, 61-875 Poznań, e-mail: agrzelak@interia.pl 
Słowa kluczowe: model przepływów międzygałęziowych, makroekonomia, gospodarka, tworzenie i podział dochodów.

Klasyfikacja JEL: E01, E10, E66.

\section{Wprowadzenie}

Procesy zachodzące $w$ gospodarce cechuje złożoność. Stwarza to potrzebę wykorzystania w makroekonomicznych ocenach wielu teorii i modeli. Jedną z takich możliwości są bilanse pieniężnych przepływów międzygałęziowych. Poprzez analizę strumieni przepływów wyrażających wartość transakcji pomiędzy dostawcami i odbiorcami (input-output) model konkretyzuje idee funkcjonowania gospodarki (mechanizmu rynkowego i budżetowego), jego wewnętrzne powiązania, struktury i zależności oraz efekty decydujące o procesach reprodukcji. Pomimo że ten nurt badań nie znalazł się na razie w Polsce w centrum zainteresowania, to może być użytecznym instrumentem oceny funkcjonowania gospodarki w ujęciu zagregowanym w pespektywie wieloletniej [Tomaszewicz 1994]. Jest to tym bardziej uzasadnione, że istnieją interesujące przesłanki dalszego rozwoju podejścia input-output $\mathrm{w}$ analizach ekonomicznych [Boratyński, Przybyliński i Świerczewska 2015]. Wykorzystując założenia teorii równowagi ogólnej, model ten umożliwia analizę tworzenia i podziału wytworzonych efektów makroekonomicznych oraz oddziaływania procesów globalnych na gospodarkę poprzez eksport i import. Walorem modelu jest możliwość wnioskowania dedukcyjnego, co pozwala na jego szerokie wykorzystanie, także w kształceniu na studiach ekonomicznych. Nie bez znaczenia jest również uniwersalność modelu w przypadku badania współzależności zachodzących w obrębie gospodarek danych krajów, w tym oceny efektów zmian aktywności gospodarczej [Bess i Ambargis 2011]. Świadczy też o tym analiza cech systemów gospodarczych niezależnych od sposobu regulacji produkcji i jej podziału [Leontief 1936, Stankiewicz 2007]. Z drugiej strony trzeba zauważyć, że znaczny zakres agregacji danych wymaga ostrożności w interpretacji tablicy przepływów międzygałęziowych [Lonc 1985].

Celem artykułu jest przedstawienie możliwości wykorzystania modelu przepływów międzygałęziowych w analizach makroekonomicznych gospodarki oraz sformułowanie konkluzji co do możliwości poszerzenia jego zastosowania w badaniach ekonomicznych. W związku z tym przedstawiono rekomendacje dotyczące modyfikacji dotychczasowego sposobu przedstawiania bilansów przepływów międzygałęziowych, stąd zaprezentowane rozważania mają charakter teoretyczny, $\mathrm{z}$ elementami postulatywnymi. 


\section{Model input-output - ujęcie retrospektywne i metodyka}

Gospodarka danego kraju składa się z wielu różnych działów ${ }^{1}$ wzajemnie ze sobą powiązanych. Związki te realizowane są poprzez transakcje kupna i sprzedaży dóbr oraz usług, które integrują wszystkie podmioty gospodarcze. Wymiernym efektem tych transakcji są strumienie, które mają charakter strukturotwórczy, a ponadto ich wartość decyduje o sile zależności pomiędzy działami ${ }^{2}$. Istnienie przepływów produktów (usług) między działami w gospodarce stwarza zapotrzebowanie na analizę nakładów i wyników w skali poszczególnych działów (grup przedsiębiorstw) oraz całej gospodarki. Teoretyczne podstawy rozwoju modelu wynikają z uproszczonej wersji klasycznej teorii równowagi ogólnej nawiązującej do opisu zależności gospodarki zarówno w zakresie tworzenia PKB, jak i jego struktur. Ponadto model input-output jest na tyle elastycznym instrumentem, że umożliwia ocenę funkcjonowania gospodarek w różnych systemach gospodarczych zgodnie z metodyką liczenia agregatów makroekonomicznych zarówno według MPS (material product system), jak i SNA (system of national account). W pierwszym przypadku uwzględniane były jedynie działy produkcyjne, a więc wytwarzające dobra i usługi materialne, przy założeniu, że sfera niematerialna jest redystrybuowana poprzez budżet (spożycie zbiorowe). Z kolei w przypadku metody SNA uwzględniana jest pełna aktywność gospodarcza badanych podmiotów.

Pierwszym, który zauważył i wykorzystał sens analizy przepływów dóbr w gospodarce, był F. Quesnay, nadworny lekarz Ludwika XV, który w formie tablicy ekonomicznej przedstawił transfery dóbr między trzema działami gospodarki: rolnictwem (klasa produkcyjna), sferą pozarolniczą (klasa jałowa) i właścicielami (władza świecka i duchowna) [Quesnay 1928]. Na tej podstawie określił współzależności sfery wytwórczej gospodarki, podziału wytworzonego produktu społecznego oraz sfery dochodowej, odpowiadając na pytanie, kto i jakiego rodzaju otrzymuje dochód.

Kolejnym etapem rozwoju tego podejścia były marksowskie schematy reprodukcji (1) i (2):

$$
\begin{gathered}
P_{1}=c_{1}+v_{1}+m_{1}, \\
P_{2}=c_{2}+v_{2}+m_{2}, \\
c_{2}=v_{1}+m_{1} .
\end{gathered}
$$

${ }^{1}$ Dział gospodarki rozumiany jest w artykule tak jak w opracowaniach GUS.

${ }^{2}$ W tym przypadku należy uwzględnić stopień agregacji działów. Przykładowo, za 2010 r. GUS w publikowanych danych przepływów międzygałęziowych dokonał podziału na 77 działów, a w 2005 r. było to tylko 55 działów. Wzrost liczby działów sprzyja większej szczegółowości analiz, ale z drugiej strony może utrudniać syntetyczne oceny. 
Całkowity produkt globalny $P$ niezbędny do wyprodukowania danego produktu równy jest sumie $c$ (wartości zużytych środków produkcji) oraz kosztu siły roboczej $V$ i wartości produktu dodatkowego $m$ [Marks 1955]. W celu zachowania równowagi przepływów pomiędzy działem pierwszym (środki produkcji) i drugim (środki konsumpcji) musi być spełniony warunek równowagi (2). Koncepcję teorii równowagi ogólnej, przez przedstawienie powiązanych układów równań produkcji w warunkach cen wolnokonkurencyjnych, skonkretyzował L. Walras [1926]. Najbardziej przejrzystym modelem związków typu dostawcaodbiorca jest zapis szachownicowy przepływów rzeczowo-finansowych W. Leontiefa [1963], który przyjmujemy za podstawę dalszych rozważań. Jego istota sprowadza się do założenia, że gospodarka narodowa stanowi agregat zasobów i strumieni składających się z kilku sprzężonych ze sobą układów, które opisano metodą nakładów i wyników (input-output) w formie tabelarycznej (szachownicowej) - tabela 1 .

Tabela 1. Wzorcowy układ tabelaryczny przepływów międzygałęziowych

\begin{tabular}{|c|c|c|c|c|c|c|c|}
\hline \multirow{2}{*}{$i$} & \multirow{2}{*}{$\begin{array}{c}\text { Produkcja } \\
\text { globalna }\end{array}$} & \multicolumn{3}{|c|}{ Stadia pośrednie } & \multicolumn{3}{|c|}{ Odbiorcy końcowi } \\
\hline & & 1 & 2 & $j$ & razem & $C$ & $I$ \\
\hline 1 & $X_{1}$ & \multirow{4}{*}{$\begin{array}{c}w_{11} \\
w_{21} \\
\cdot \\
w_{i 1}\end{array}$} & \multirow{4}{*}{$\begin{array}{c}w_{12} \\
w_{22} \\
\cdot \\
w_{i 2}\end{array}$} & \multirow{4}{*}{$\begin{array}{c}\ldots w_{1 j} \\
\ldots w_{2 j} \\
\ldots \\
\ldots w_{i j}\end{array}$} & $x_{1}$ & $C_{1}$ & $I_{1}$ \\
\hline 2 & $X_{2}$ & & & & $x_{2}$ & $C_{2}$ & $I_{2}$ \\
\hline . & . & & & & $\cdot$ & $\cdot$ & . \\
\hline$i$ & $X_{i}$ & & & & $x_{i}$ & $C_{i}$ & $I_{i}$ \\
\hline$i+1$ & $V$ & $V_{1}$ & $V_{2}$ & $\ldots V_{j}$ & & & \\
\hline$i+2$ & $S$ & $S_{1}$ & $S_{2}$ & $\ldots S_{j}$ & & & \\
\hline Ogółem & $X$ & $X_{1}$ & $X_{2}$ & $\ldots X_{j}$ & & & \\
\hline
\end{tabular}

Oznaczenia: $w_{i j}$ - wartość przepływów pomiędzy działami, $V$ - płace, $S$ - nadwyżka operacyjna brutto plus podatki, $C$ - konsumpcja, $I$ - inwestycje.

Źródło: [Leontief 1963].

Przyjęto założenie, że produkt każdego działu (output) może służyć jako środek produkcji (input) w każdym innym dziale bądź inwestycji lub jako środek konsumpcji. Model Leontiefa zawiera trzy części. Pierwsza przedstawia transakcje pomiędzy przedsiębiorstwami zgrupowanymi w gałęzie. Odzwierciedla więc ona popyt pośredni. Druga część obrazuje wielkość i strukturę popytu przeznaczonego dla odbiorców końcowych. Z kolei trzecia przedstawia wielkość i strukturę dochodów poszczególnych gałęzi. W dalszym etapie rozwoju tego modelu P. Samuelson [1951] i R. Solow [1959] dokonali jego rozszerzenia, wykorzystując metody optymalizacyjne. $Z$ podejścia tego powstały także równania równowagi przepływów międzygałęziowych (3) [Lange 1961]. Lewa strona tego równania określa, 
co pobiera (zakupuje) i wytwarza dany dział produkcji, a prawa, co sprzedaje pozostałym działom (3):

$$
\sum_{i=1}^{n} w_{i j}+V_{j}+S_{j}=\sum_{j=1}^{m} w_{i j}+x_{i} \quad(i=1,2, \ldots, n ; j=1,2, \ldots, m),
$$

gdzie:

$w_{i j}$ - nakłady na środki produkcji,

$V_{j}$ - nakłady na płace,

$S_{j}$ - wartość dodatkowa (nadwyżka operacyjna brutto + podatki - według SNA),

$x_{i}-$ produkt (popyt) końcowy danego działu.

Wykorzystując podejście W. Leontiefa, stworzono wiele modyfikacji modelu przepływów międzygałęziowych. Idea przepływów międzygałęziowych ma swój wymiar zarówno teoretyczny, głęboko osadzony w historii myśli ekonomicznej, jak i aplikacyjny, związany z publikowaniem przez urzędy statystyczne stosownych bilansów. W tym miejscu przedstawimy przykładową interpretację tablicy, wykorzystywaną do objaśniania współzależności gospodarczych (tabela 2). Podejście to zawiera interpretację modelu dla jego czterech części. Uwagę zwraca występowanie w tablicy ćwiartki IV, która w praktyce rzadko jest wypełniana ${ }^{3}$. W ćwiartce I (lewa górna część tablicy) zawarto popyt pośredni zgłaszany przez działy gospodarki. Zostały tu zaprezentowane wzajemne transakcje między działami. W wierszach przedstawiony został strumień popytu pośredniego. Są to zakupy produktów (usług), które służą dalszemu przetworzeniu. Kolumny natomiast interpretujemy jako strukturę kosztów bezosobowych poszczególnych działów [Czyżewski 2011]. W części II tablicy przedstawiono popyt końcowy: konsumentów indywidualnych, budżetu, sektora bankowego, inwestorów oraz restytucyjny. Na podstawie zawartych tam danych można dokonać oceny strumieni odnoszących się do rozdysponowania produktów danych działów służących zaspokojeniu finalnego popytu przez podmioty gospodarcze. Jednocześnie ta ćwiartka tablicy może być też rozpatrywana przez pryzmat popytu potencjalnego, tj. aspiracji wyróżnionych podmiotów. Popyt, do którego aspirują, jest wyższy od efektywnego (zrealizowanego). Różnica między tymi kategoriami na gruncie ekonomii keynesowskiej sprowadza się do istnienia luki popytowej. W gospodarce rynkowej uwidocznione jest to poprzez występowanie nierównowagi podażowej.

${ }^{3}$ W materiałach GUS w Polsce w odniesieniu do przepływów publikowane są tylko trzy części. Wynika to stąd, że na poziomie zagregowanym pomija się cześć czwartą dotyczącą podziału dochodów. Niemniej jednak procesy, które związane są z tym zjawiskiem, są istotne dla funkcjonowania gospodarki i dlatego w rozważaniach w niniejszym artykule podział dochodów został uwzględniony na poziomie teoretycznym [Czyżewski 2011]. 


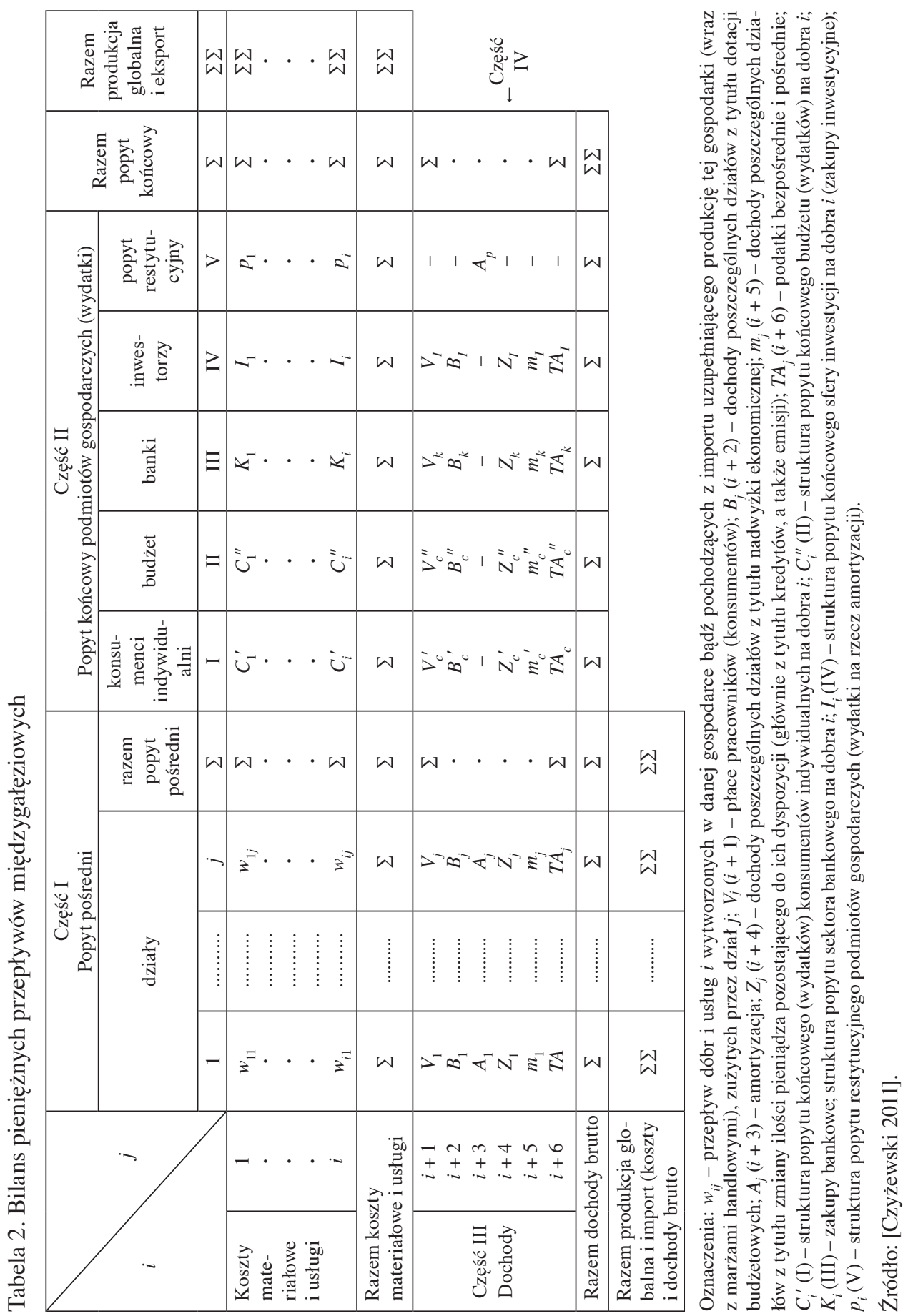


Produkcja, która w uproszczeniu może być odzwierciedleniem łącznego popytu, do którego podmioty aspirują, nie znajduje realnego (efektywnego) popytu w warunkach rynkowych. Rośnie więc presja na konsumenta poprzez działania promocyjne.

Ćwiartka III tablicy przepływów (lewa dolna część tablicy) pokazuje dochody i ich strukturę, które zostały wytworzone w poszczególnych działach gospodarki. W wierszach wyróżnione są poszczególne elementy wartości dodanej, m.in. płace, nadwyżka ekonomiczna. W oddzielnych wierszach zapisano wpływ budżetu państwa i banków na dochody przedsiębiorstw, poprzez m.in. dochody z tytułu zmiany ilości pieniądza emisyjnego i kredytowego oraz podatki. Na podstawie informacji zawartych w tej ćwiartce tablicy możemy określić makroekonomiczne efekty działalności poszczególnych działów, w tym zwłaszcza w postaci wartości dodanej. Część IV tablicy dotyczy wtórnego podziału wytworzonych dochodów, które z kolei służą realizacji popytu finalnego ${ }^{4}$. W tej ćwiartce tablicy dochód zostaje rozdzielony pomiędzy podmioty występujące w gospodarce: konsumentów indywidualnych, budżet, bank oraz inwestorów. Po stronie dochodów budżetu uwzględnia się głównie wpływy z podatków i opłat, ale także z innych tytułów, np. zysków przedsiębiorstw państwowych. Z kolei wydatki obejmują środki przeznaczone na konsumpcję zbiorową, inwestycje, dotacje i subwencje, a także ewentualny podział wpływów z innych tytułów. W odniesieniu do banków zawiera ona informacje o wpływach $\mathrm{z}$ racji otwieranych rachunków i emisji pieniądza oraz wydatków z tytułu kredytów obrotowych i inwestycyjnych. Taka konstrukcja tablicy gwarantuje możliwość obserwacji zarówno strony rzeczowej, jak i finansowej przepływów [Czyżewski 2011], np. procesy globalizacji oddziałują na tę część bilansu przepływów międzygałęziowych poprzez presję wywieraną na zmniejszenie roli państwa w procesach gospodarczych [Czyżewski i Grzelak 2009].

Warto w tym miejscu podkreślić, że model przepływów międzygałęziowych stosowany współcześnie w praktyce gospodarczej zakłada, iż II i III ćwiartka tablicy wystarczą do interpretacji procesów równowagi gospodarczej (tabela 3). Tym samym przyjmuje się, że produkt krajowy brutto wytworzony (PKB) równy jest podzielonemu, tak jakby nie występowała nierównowaga gospodarcza (tu podażowa), a popyt efektywny równy był potencjalnemu, do którego aspirują uczestnicy rynku, co jest oczywiście założeniem idealizującym.

${ }^{4}$ W praktyce gospodarczej w Polsce wykorzystywano ją jedynie sporadycznie w celu koordynacji strony finansowej planów gospodarczych. Ostatnie publikowane dane z tego zakresu dotyczą bilansu gospodarki polskiej za 1957 r. [Opracowanie Biura Ekonomicznego NBP... 1958]. 


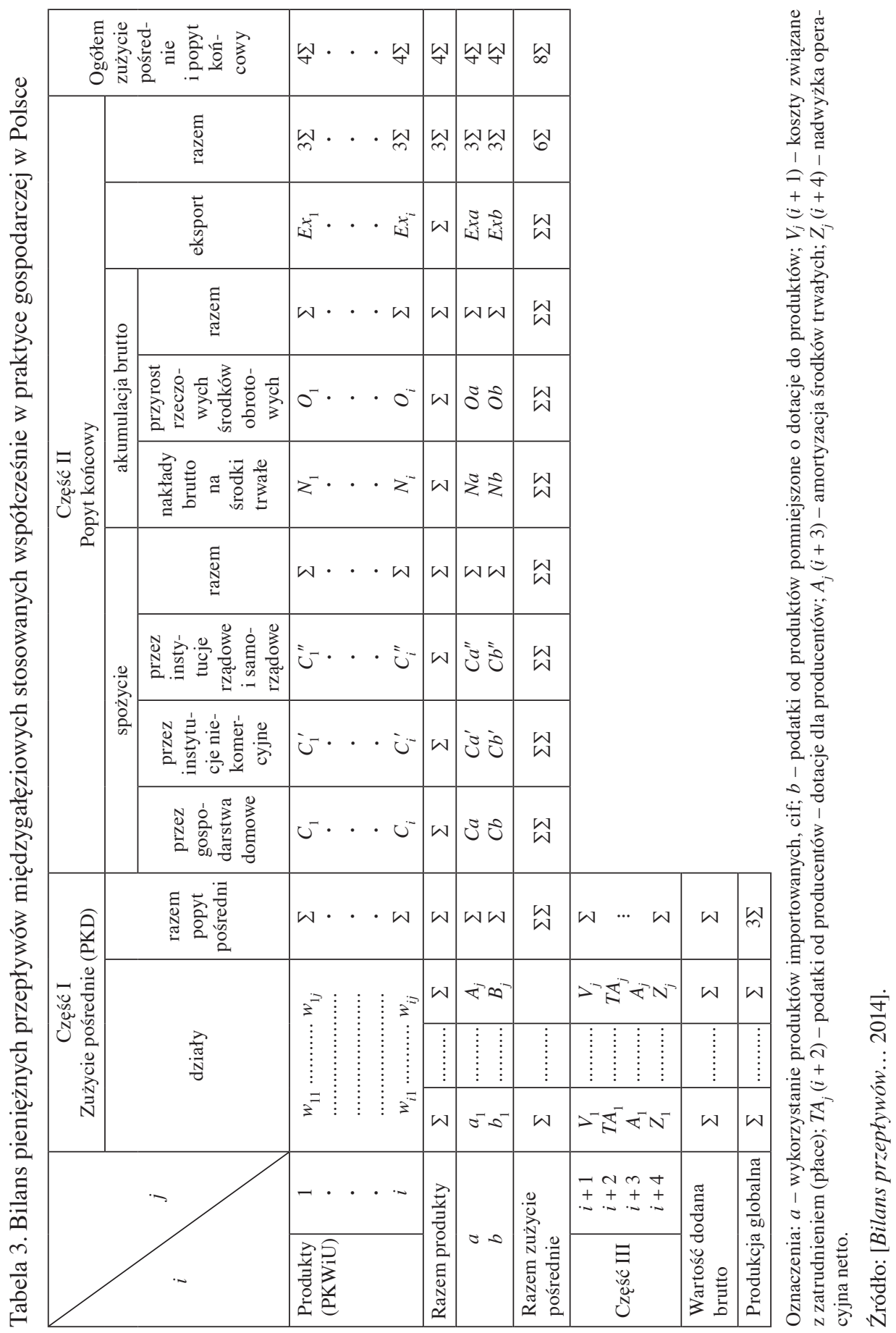




\section{Zastosowania makroekonomiczne modelu input-output - ujęcie teoretyczne}

Istnieje wiele możliwości wykorzystania przepływów międzygałęziowych do oceny funkcjonowania gospodarki. Chodzi tu o identyfikację związków pomiędzy działami w gospodarce zachodzących poprzez przepływy międzygałęziowe, jak również ich znaczenie w tworzeniu produktu globalnego czy wartości dodanej. Wykorzystać tu można $n$-równań opisujących równowagę nakładów i efektów (4) w całej gospodarce:

$$
X_{i}-\sum_{i=1}^{n} w_{i j}=x_{i} \quad(i=1,2, \ldots, n ; j=1,2, \ldots, m),
$$

gdzie:

$X_{i}$ - produkcja globalna,

$w_{i j}$ - wartość przepływów pomiędzy działami,

$x_{i}$ - produkcja (popyt) finalna $\mathrm{w} i$-tym dziale.

Bilanse przepływów międzygałęziowych mogą służyć także do oceny struktury strumieni produktów „zasilających” dany dział (odpowiednie kolumny w I części tablicy przepływów międzygałęziowych). Pozwala to na określenie zakresu samozaopatrzenia czy wzajemnych powiązań pomiędzy działami w układzie przedmiotowym i dynamicznym (dla ujęć wieloletnich). Oceniając z kolei struktury rozdysponowania produktów danych działów, a w szczególności elementy popytu końcowego (spożycie, akumulację), można dokonać oceny ich pozycji w gospodarce. W literaturze dotyczącej tego tematu można znaleźć wiele przykładów takiego rodzaju zastosowań przepływów międzygałęziowych, szczególnie w przypadku gospodarki żywnościowej [Mrówczyńska-Kamińska 2015, Grzelak 2006]. Identyfikacja wzajemnych powiązań jest szczególnie istotna w przypadku programów restrukturyzacji określonych działów gospodarki. W ujęciu wieloletnim można ocenić dynamikę rozwoju poszczególnych działów, jak też charakter zmian w zakresie oceny pozycji w procesach gospodarczych.

Rozwijając ten wątek, warto zbadać strukturę nakładów bieżących, a przez odwrócenie tzw. współczynników „chłonności” określić efektywność poszczególnych rodzajów nakładów. Celowi temu służą m.in. współczynniki pracochłonności i produktochłonności (materiałochłonności), inaczej określane jako współczynniki techniczne produkcji (5):

$$
a_{i j}=\frac{w_{i j}}{X_{j}} \quad(i=1,2, \ldots, n ; j=1,2, \ldots, m),
$$

gdzie: $X_{j}$ - produkcja globalna. 
Współczynniki te można zapisać w postaci macierzy (6):

$$
A=\left[a_{i j}\right]=\left(\begin{array}{ccc}
a_{11} & \ldots & a_{1 j} \\
\ldots & \ldots & \ldots \\
a_{i 1} & \ldots & a_{i j}
\end{array}\right) .
$$

Techniczny współczynnik produkcji może charakteryzować technologię procesu produkcyjnego każdego z działów. Natomiast pod względem interpretacyjnym wskazuje, jaka wartość $i$-tego produktu danego działu jest niezbędna do wyprodukowania jednostki produkcji globalnej j-tego działu. W ten sposób model przepływów może służyć do krótkookresowego prognozowania przyszłej wartości produkcji zarówno globalnej, jak i finalnej przy założeniu niezmiennej technologii produkcji ${ }^{5}$. Mechanizm rynkowy wywołuje presję na obniżenie tych współczynników i tym samym relatywne zmniejszenie znaczenia popytu pośredniego $\mathrm{w}$ gospodarce. Związane jest to $\mathrm{z}$ wprowadzaniem innowacji, a tym samym postępem technicznym. Różne jest jednak tempo tych zmian, co przesądza o przeobrażeniach strukturalnych w gospodarce. Stąd współczynniki materiałochłonności służyć mogą także oszacowaniu międzygałęziowych dyfuzji innowacji [Wolff 2011, Świeczewska i Tomaszewicz 2012] czy identyfikacji, które w największym stopniu wpływają na wzrost potencjału innowacyjnego gospodarki [Świeczewska 2014]. Interesujący sposób wykorzystania modelu przepływów międzygałęziowych przedstawił B. Czyżewski [2013]. Na podstawie danych empirycznych dokonał szacunku międzygałęziowych przepływów rent ekonomicznych w Polsce z rolnictwa do jego otoczenia.

Podobnie jak w przypadku produktochłonności (materiałochłonności) można wyznaczyć pracochłonność poszczególnych działów (7):

gdzie:

$$
P_{j}=\frac{V_{j}}{X_{j}} \quad(j=1,2, \ldots, m),
$$

$P_{j}$ - pracochłonność,

$V_{j}$ - koszty wynagrodzen,

$X_{j}$ - produkcja globalna.

Określa się w tym przypadku relację kosztów wynagrodzeń na jednostkę produkcji globalnej danego działu. Zmniejszenie tej relacji wskazuje na wzrost wydajności pracy i tym samym bardziej efektywne wykorzystanie zasobów pracy.

${ }^{5} \mathrm{~W}$ literaturze dotyczącej tego tematu istnieje wiele przykładów takich zastosowań, np. modele CGE (computable general equilibrium) [Handbook... 2013] czy modele zintegrowane (input-ouput econometric models). 
Z drugiej jednak strony należy mieć świadomość, że wiązać się to może ze zwiększeniem bezrobocia i wzrostem obciążeń socjalnych budżetu państwa.

Analiza tablicy przepływów międzygałęziowych pozwala także na ocenę efektywności makroekonomicznej poszczególnych działów gospodarki. Rozumiana może być ona jako udział wartości dodanej brutto w łącznej wartości dodanej brutto wytworzonej w gospodarce lub w produkcji globalnej danego działu (8):

gdzie:

$$
E_{j}=\frac{W D_{j}}{X_{j}} \quad(j=1,2, \ldots, m),
$$

$E_{j}$ - efektywność makroekonomiczna działu $j$,

$W D_{j}$ - wartość dodana działu $j$,

$X_{j}$ - produkcja globalna.

Relacja ta pozwala wstępnie określić dysparytety rozwojowe w gospodarce i tym samym dostosować instrumenty polityki gospodarczej z uwzględnieniem paradygmatu rozwoju zrównoważonego.

Kolejnym sposobem określania efektywności może być ocena relacji popytu końcowego do wartości strumieni zasilających dany dział (innymi słowy, jest to wskaźnik efektywności powiązań międzygałęziowych) [Czyżewski i Grzelak 2007] (9):

$$
E_{p m}=\frac{x_{i}}{\sum_{i=1}^{n} w_{i j}},
$$

gdzie:

$E_{p m}$ - efektywność powiązań międzygałęziowych,

$x_{i}$ - produkcja (popyt) finalna w $i$-tym dziale,

$w_{i j}$ - wartość przepływów pomiędzy działami.

Wskaźniki efektywności służą do określenia pozycji konkurencyjnej danego działu względem pozostałych działów. Pośrednio mogą także wskazywać na transfer wypracowanych już efektów i rent do otoczenia (głównie poprzez system cen). Określają także poprawę bądź pogorszenie rozwoju danego działu przez pryzmat kreacji efektów dochodowych. Ponadto związki te mogą stanowić podstawę do konturowania symulacji makromodeli. Istnieje wiele opracowań dotyczących wykorzystania modelu input-output do oceny efektywności działów, np. działu rolnego [Woś 1973, Czyżewski i Smędzik-Ambroży 2015]. Należy w tym miejscu podkreślić, że omawiane współczynniki efektywności powiązań międzygałęziowych obarczone są uproszczeniem wynikającym z techniczno-bilansowego ujęcia danych w tablicy przepływów międzygałęziowych. Chodzi tu o założenie jednoczesnej transformacji nakładów w efekty, tj. brak odroczenia 
w czasie [Czyżewski i Helak 1991]. Nie przekreśla to jednak wnioskowania o zaistniałych tendencjach w tym zakresie.

Powiązanie działów gospodarki z zagranicą można analizować przez pryzmat zmian udziału eksportu w łącznym bądź finalnym popycie na produkty (usługi), jak również z perspektywy importochłonności danego działu. Pierwsza z wymienionych możliwości pozwala na ocenę zmian konkurencyjności zewnętrznej. W przypadku natomiast współczynnika importochłonności (bezpośredniej), definiowanej jako wartość produktów zużytych bezpośrednio przez dział, a pochodzących z importu, ocenić możemy znaczenie „zasileń” przez strumienie produktów z importu. Tablica przepływów międzygałęziowych może być również wykorzystana do oceny dynamiki poszczególnych składników przy porównaniach wieloletnich. Chodzi w szczególności o te elementy, które związane są ze zmianami popytu finalnego na produkty danego działu, wartości dodanej czy strumieni dóbr i usług zasilających dany dział. Istotne znaczenie w tym przypadku ma wycena poszczególnych składników, a zwłaszcza zastosowanie właściwych deflatorów przy porównaniach w cenach stałych.

\section{Możliwości uzupełnienia statystyki bilansów przepływów międzygałęziowych*}

Dotychczasowe doświadczenia związane z wykorzystaniem bilansów przepływów międzygałęziowych do ocen makroekonomicznych pozwalają na sformułowanie określonych rekomendacji. Najważniejszy z postulatów dotyczy potrzeby wypełnienia IV ćwiartki tablicy przepływów. Brak tego istotnie ogranicza możliwości analizy w zakresie podziału PKB i związanych z tym procesów redystrybucji budżetowej, a także efektywności polityki fiskalnej. Na poziomie zagregowanych ocen umożliwiłoby to pełniejsze określenie roli budżetu państwa w procesach rozwojowych gospodarki.

Innym zagadnieniem jest kwestia nierównowagi podażowej ocenianej z perspektywy bilansów w modelu przepływów międzygałęziowych. Zarówno popyt efektywny (zrealizowany), wytworzone dochody, jak i podzielone efekty teoretycznie powinny być sobie równe. Wynika to z tożsamości w rachunku makroekonomicznym. Strumienie wydatków podmiotów gospodarczych powinny pokrywać się z łącznymi ich dochodami za pośrednictwem mechanizmu rynkowego. Jak wobec tego wyjaśnić realnie występującą nierównowagę rynkową, tzn. podażową? Gospodarka w tych warunkach nie wykorzystuje zazwyczaj wszystkich swoich możliwości w sensie pełnego wykorzystania zdolności produkcyj-

* Opracowano na podstawie [Czyżewski i Grzelak 2012]. 
nych. W tym przypadku można mówić, używając terminologii keynesowskiej, o równowadze, ale w warunkach niepełnego wykorzystania mocy wytwórczych w gospodarce (luka popytowa). Sytuacja ta przejawia się nadwyżką produkcji nad popytem, wzrostem poziomu zapasów czy niewykorzystanymi mocami wytwórczymi. W modelu przepływów międzygałęziowych mogłoby to zostać uwidocznione w niezrealizowanych aspiracjach konsumentów i producentów w II ćwiartce tablicy przepływów. Chodzi w szczególności o uwzględnienie zarówno zapasów, oszczędności podmiotów, jak i szacunku alternatywnej wielkości popytu potencjalnego ponad poziom naturalnej stopy bezrobocia. Wówczas w ćwiartce IV przedstawiony mógłby być popyt efektywny, tj. zrealizowany, natomiast w ćwiartce II popyt potencjalny, który byłby wyższy (co do aspiracji popytowych) od łącznej wartości ćwiartki III przedstawiającej dochody będące do dyspozycji podmiotów gospodarczych. Skutkiem nierównowagi są nadwyżkowe zapasy i niewykorzystane zasoby produkcyjne (zwłaszcza pracy) i związane z tym bezrobocie. Można to także interpretować jako nienadążanie opłaty pracy realnej w odniesieniu do wzrostu wydajności i (lub) jako niższą wydajność podatkową podmiotów gospodarczych, co wiąże się z problem ukrywania dochodów czy cenami transferowymi [Czyżewski i Grzelak 2009]. W związku z powyższym interesujące byłoby oszacowanie przybliżonej ${ }^{6}$ nierównowagi poprzez przedstawienie (alternatywnie) w ćwiartce II popytu potencjalnego, tj. efektywnego, oraz niezrealizowanych aspiracji. Ponadto rozwinięcie tego podejścia umożliwiłoby oszacowanie nierównowagi podażowej na poziomie poszczególnych działów. Stanowiłoby to przesłankę precyzyjnie zaadresowanej polityki gospodarczej w zakresie stosowania nieautomatycznych stabilizatorów koniunktury. Wypełnienie IV ćwiartki tablicy przepływów międzygałęziowych pozwoli także na pogłębienie interpretacji odnoszącej się do oceny relacji pieniężnych w gospodarce. Chodzi m.in. o szacunkowe zaprezentowanie (w ćwiartce III) wielkości depozytów i kredytów (lub nowo otwieranych/udzielanych) dla poszczególnych działów gospodarki i na konkretyzację skutków oddziaływania polityki pieniężnej, działalności banków, w tym kreacji pieniądza dla procesów gospodarczych.

Istnieje także możliwość pełnego wykorzystania modelu input-output do badań w skali regionalnej. Pozwolą one na odniesienie sytuacji ekonomicznej danego działu w województwie do sytuacji ogólnokrajowej, co umożliwi identyfikację stymulant i destymulant rozwojowych w poszczególnych regionach czy ocenę ekonomiczną konkretnych przedsięwzięć inwestycyjnych. Zastosowanie modelu przepływów międzygałęziowych w badaniach regionalnych pozwoliłoby na pełniejsze dopasowanie lokalnej aktywności gospodarczej do istniejących potrzeb, uwzględniając zewnętrzne (względem regionu) rynki zbytu. $\mathrm{Z}$ reguły jednak

${ }^{6}$ Przybliżonej w tym sensie, że nie sposób jest zaprezentować wszystkich aspektów nierównowagi podażowej, takich chociażby jak niewykorzystane zasoby produkcyjne. 
urzędy statystyczne nie publikują tablic input-output w układzie regionalnym. Istnieje jednak możliwość samodzielnej dekompozycji danych zawartych w tablicy przepływów na podstawie programowania matematycznego czy współczynników lokalizacji w celu stworzenia stosownych macierzy regionalnych. W literaturze dotyczącej tego zagadnienia jest niewiele przykładów takiego kierunku wykorzystania modelu przepływów międzygałęziowych [Malaga 1992, Tomaszewicz i Trębska 2005, Zawalińska 2009]. Przepływy regionalne konstruowane są przez urzędy statystyczne np. w Finlandii i Hiszpanii. Warto też nadmienić, że istnieje możliwość wykorzystania podejścia input-output w modelu CGE (computable general equilibrium - model równowagi ogólnej). F. Perali, L. Pieroni i G. Standardi [2012], wykorzystując ten model, badali wpływ zniesienia ceł w światowym handlu produktami rolnymi na gospodarki krajów Unii Europejskiej (UE-15). W ten sposób możliwe stało się wskazanie krajów (działów), które relatywnie skorzystają lub stracą na liberalizacji handlu.

Wobec narastającej potrzeby wykorzystania zmiennych środowiskowych do oceny rozwoju gospodarczego pojawiły się też zmodyfikowane koncepcje tablic przepływów międzygałęziowych [Duchin i Steenge 2007, Plich 2002]. Chodzi w tym przypadku o odpowiednie uwzględnienie w macierzach po stronie efektów (output) emisji dwutlenku węgla i innych gazów cieplarnianych. W ten sposób ocena funkcjonowania badanych podmiotów staje się pełniejsza, gdyż uwzględnia ujemne efekty zewnętrzne. Modele tego typu z jednej strony wciąż są wyzwaniem, z drugiej jednak są koniecznością w świetle współcześnie obserwowanych tendencji rozwoju gospodarki światowej.

Publikowanie pełnych bilansów międzygałęziowych w Polsce co 5 lat i to z dużym przesunięciem czasowym (ok. 4-letnim) znacznie ogranicza ich praktyczne wykorzystanie, jeśli chodzi o bieżące monitorowanie zjawisk gospodarczych. Uzasadniony jest zatem postulat, aby publikacje te ukazywały się częściej (np. co 3 lata) i szybciej, maksymalnie z 2-letnim opóźnieniem. Ważne jest też, by dawały podstawę do pełnej oceny podziału wytworzonych dochodów i były komplementarne z ujednoliconymi tablicami publikowanymi przez OECD dla 40 krajów [The World... 2012]. Umożliwiałoby to prowadzenie międzynarodowych porównań funkcjonowania gospodarek i ich poszczególnych działów.

\section{Podsumowanie}

Rozważania zawarte w artykule skłaniają do kilku konkluzji:

1. Wykorzystanie w badaniach podejścia input-output stanowi komplementarny instrument oceny i interpretacji zjawisk gospodarczych, umożliwiający pogłębienie analiz makroekonomicznych. Chodzi tu przede wszystkim o inter- 
pretację związków, jak również zdiagnozowanie źródeł zróżnicowanego rozwoju pomiędzy działami w obrębie gospodarki danego kraju, czy też zmian pozycji rynkowej badanych działów gospodarki. Nie bez znaczenia jest także wykorzystanie modelu w symulacjach jako narzędzia do oceny wpływu polityki gospodarczej czy szoków egzogenicznych (nowe technologie, odkrycia złóż) na wielkości makroekonomiczne i gałęziowe.

2. Ocena funkcjonowania gospodarki z wykorzystaniem modelu przepływów międzygałęziowych w ujęciu dynamicznym pozwala na ocenę przeobrażeń strukturalnych $w$ ramach danej gospodarki. Zrozumienie ich charakteru i tendencji jest szczególnie przydatne w kreowaniu polityki gospodarczej państwa w zakresie stosowania nieautomatycznych stabilizatorów koniunktury.

3. Istnieje potrzeba rozbudowy modelu przepływów międzygałęziowych o czwartą część i tym samym publikacji danych dotyczących podziału wytworzonych dochodów oraz szerszego uwzględnienia w praktyce gospodarczej cech opisujących sferę pieniężną. Intersująca byłaby próba wykorzystania modelu przepływów do przedstawienia skali nierównowagi podażowej zarówno pomiędzy poszczególnymi częściami tego modelu, tj. dochodu do dyspozycji (III), popytu efektywnego, potencjalnego (II) oraz realnego podziału wytworzonych dochodów (IV), jak i w ramach poszczególnych działów. Istnieją także możliwości skonstruowania regionalnych modeli przepływów międzygałęziowych, co dałoby szansę na zwiększenie skuteczności działań w ramach różnych rodzajów polityki regionalnej. Wyzwaniem jest również uwzględnienie zmiennych środowiskowych w analizach input-output.

4. Można sądzić, że będziemy mieć do czynienia z dalszym rozwojem modeli wykorzystujących metodę input-output w miarę doskonalenia aparatu ekonometrycznego, budowy bardziej złożonych modeli prognostycznych z uwzględnieniem powiązań globalnych, kontekstu środowiskowego czy dezagregacji danych do poziomu regionalnego [Dietzenbacher $i$ in. 2013].

\section{Literatura}

Bess R., Ambargis Z. [2011], Input-Output Models for Impact Analysis: Suggestions for Practitioners Using RIMS II Multipliers, Presented at the $50^{\text {th }}$ Southern Regional Science Association Conference, Louisiana.

Bilans przepływów międzygatęziowych w bieżqcych cenach bazowych w 2010 r. [2014], GUS, Warszawa.

Boratyński J., Przybyliński M., Świeczewska I. [2015], Metody input-output: wybrane kierunki rozwoju [w:] Nauczyciel akademicki wobec nowych wyzwań edukacyjnych, red. P. Wdowiński, Wydawnictwo Uniwersytetu Łódzkiego, Łódź.

Czyżewski A. [2011], Przepływy międzygałęziowe jako makroekonomiczny model gospodarki, Wydawnictwo Uniwersytetu Ekonomicznego w Poznaniu, Poznań. 
Czyżewski A., Grzelak A. [2007], The Use of Input-Output to Evaluate the Agriculture Situation in Poland after 1990, „Management”, vol. 11, nr 2.

Czyżewski A., Grzelak A. [2009], Możliwości oceny rozwoju rolnictwa w warunkach globalnych z zastosowaniem tabeli przepływów międzygałęziowych, ,Roczniki Naukowe SERiA", t. XI, z. 2.

Czyżewski A., Grzelak A. [2012], Możliwości wykorzystania statystyki bilansów przepływów międzygałęziowych, ,Przegląd Statystyczny”, nr 1.

Czyżewski A., Helak K. [1991], Przekształcenia w kompleksie gospodarki żywnościowej w Polsce, „Wieś i Rolnictwo”, nr 3.

Czyżewski A., Smędzik-Ambroży K. [2015], The Efficiency of the Agricultural Sector in Poland in the Light Output-Input Model, „Management”, vol. 19, nr 1, https://doi.org/ 10.1515/manment-2015-0009.

Czyżewski B. [2013], Renty ekonomiczne w gospodarce żywnościowej w Polsce, PWE, Warszawa.

Dietzenbacher E., Lenzen M., Los B., Guan D., Lahr M.L., Sancho F., Suh S., Yang C. [2013], Input-Output Analysis: The Next 25 Years, „Economic Systems Research”, vol. 25, nr 4, https://doi.org/10.1080/09535314.2013.846902.

Duchin F., Steenge A. [2007], Mathematical Models in Input-Output Economics, Rensselaer Polytechnic Institute, Working Papers in Economics, http://www.economics.rpi. edu/workingpapers/rpi0703.pdf (data dostępu: grudzień 2016).

Grzelak A. [2006], Powiqzania rolnictwa z otoczeniem z perspektywy bilansów przepływów międzygatęziowych w warunkach transformacji systemowej, „Polityka Gospodarcza", nr 13.

Handbook of Computable General Equilibrium Modeling [2013], eds P.B. Dixon, D. Jorgenson, vol. 1A and 1B, North-Holland.

Lange O. [1961], Teoria reprodukcji i akumulacji, PWN, Warszawa.

Leontief W. [1936], Quantitative Input and Output Relations in the Economic System of the United States, ,The Review of Economics and Statistics”, vol. 18, nr 3 (August), https://doi.org/10.2307/1927837.

Leontief W. [1963], Studia nad strukturq gospodarki amerykańskiej, PWN, Warszawa.

Lonc T. [1985], Zwiqzki rolnictwa z gospodarkq narodowq na poczqtku lat 1980-tych, „Zagadnienia Ekonomiki Rolnej”, nr 6.

Malaga K. [1992], Struktura produkcyjna gospodarki żywnościowej Wielkopolski w świetle przepływów międzygałęziowych [w:] Gospodarka żywnościowa w Polsce i regionie, red. A. Czyżewski, PWE, Warszawa.

Marks K. [1955], Kapitat, t. 2, Książka i Wiedza, Warszawa.

Mrówczyńska-Kamińska A. [2015], Gospodarka żywnościowa w krajach Unii Europejskiej. Kierunki rozwoju, przepływy i współzależności, Wydawnictwo Uniwersytetu Przyrodniczego w Poznaniu, Poznań.

Opracowanie Biura Ekonomicznego NBP [1958], NBP, Warszawa.

Perali F., Pieroni L., Standardi G. [2012], World Tariff Liberalization in Agriculture: An Assessment Using a Global CGE Trade Model for EU15 Regions, ,Journal of Policy Modeling", vol. 34, nr 2, https://doi.org/10.1016/j.jpolmod.2012.01.002.

Plich M. [2002], Budowa i zastosowanie wielosektorowych modeli ekonomiczno-ekologicznych, Wydawnictwo Uniwersytetu Łódzkiego, Łódź.

Quesnay F. [1928], Pisma wybrane, tłum. B.J. Pietkiewiczówna, Gebethnber i Wolf, Warszawa. 
Wykorzystanie modelu przepływów międzygałęziowych...

Samuelson P. [1951], Abstract of a Theorem Concerning Substitutability in Open Leontief Model [w:] Activity Analysis in Production and Allocation, ed. T. Koopmans, John Wiley and Sons, New York.

Solow R. [1951], Competitive Valuation in a Dynamic Input-Output System, „Econometrica", vol. 27, nr 1.

Stankiewicz W. [2007], Historia myśli ekonomicznej, PWE, Warszawa.

Świeczewska I. [2014], The Externalities of Enterprises' Innovative Activity - An Input-Output Approach, „Folia Oeconomica Stetinensia”, vol. 13, nr 3, https://doi.org/ 10.2478/foli-2013-0023.

Świeczewska I. Tomaszewicz Ł. [2012], Rola innowacji w procesie wzrostu efektywności polskiej gospodarki. Ujęcie gatezziowe [w:] Modele i prognozy w ekonomii i finansach, red. A. Jakimowicz, Wydawnictwo Naukowe PWN, Warszawa.

Tomaszewicz Ł. [1994], Metody analizy input-output, PWE, Warszawa.

Tomaszewicz Ł., Trębska J. [2005], Regional and Interregional Input-Output Tables for Poland [w:] Modeling Economies in Transition, eds W. Welfe, P. Wdowiński, Wydawnictwo Uniwersytetu Łódzkiego, Łódź.

Walras L. [1926], Elements d'economie politique pure, R. Pichon et R. Durnad-Auzias Editeurs, Paris.

Wolff E. [2011], Spillovers, Linkages and Productivity Growth in the US Economy, 1958 to 2007, NBER Working Paper, No 16864.

The World Input-Output Database (WIOD): Contents, Sources and Methods [2012], ed. M. Timmer, WIOD Working Paper No. 10, http://www.wiod.org/ publica-tions/ papers/wiod10.pdf (data dostępu: grudzień 2016).

Woś A. [1973], Rolnictwo w bilansie przepływów międzygałęziowych, ,Zagadnienia Ekonomiki Rolnictwa", nr 1.

Zawalińska K. [2009], Regionalne efekty wsparcia Unii Europejskiej dla rozwoju obszarów wiejskich, IRWiR, Warszawa.

\section{The Use of an Input-output Model for the Macroeconomic Evaluation of the Economy}

(Abstract)

The objective of the article is to present the possibilities of using an input-output model in macroeconomic evaluations of the economy taking into account past experience and suggestions for the future. During the study we found that the input-output model is a useful tool for evaluating and interpreting economic phenomena. It can be used primarily to evaluate relationships and to diagnose the sources of diversified development between branches within a given economy. There is a need to expand the interpretation of the input-output model by adding a fourth part. This would entail publishing data on the distribution of generated income. Further, it would be interesting to attempt to use this model to present supply inequality while taking into account the environmental context of the macroeconomic analysis.

Keywords: the input-output model, macroeconomics, economy, the creation and distribution of national income. 